\title{
KAS Erika
}

\section{Távoktatási módszerek alkalmazása a köznevelésben}

\author{
„A Tanítók csak az ajtót nyitják ki, belépned neked kell!" \\ kínai közmondás
}

\section{Bevezetés}

1999 óta dolgozom a felnőttoktatásban. Tanítottam esti, levelező és intenzív képzési formában, néhány éve pedig távoktatóként is tevékenykedem. Tapasztalataim szerint a felnőtt emberek nehezen szánják rá magukat, hogy visszaüljenek a hagyományos iskolarendszer által kínált padokba. Távoktatóként úgy látom, hogy tanítványaim kedvelik ezt a képzési formát, mert alkalmazkodik egyéni életvitelükhöz. Tanulóink az oktatócsomagok mellett maguktól keresik a segítséget az Interneten, a szakirodalomban, környezetünkben. Mi valóban csak az ajtót nyitjuk ki nekik, a felfedezés rájuk vár. Ez a mai kor kihívása, ami a life long learningben konkrét útmutatókkal már meg is fogalmazódott. Megváltozott a tanulás metodikája, a pedagógus szerepe, az elvárások. Írásomban összefoglaltam a távoktatási módszerek alkalmazását elemző felmérésemet. Az intézmények megismerése során szembesülnöm kellett azzal, hogy a köznevelés rendszerében a távoktatás fogalma többrétú. Egyrészt a köznevelési törvény értelmében meghatározott képzési formát jelenti. Másrészt a távoktatás alternatívájaként gyakran jelenik meg az elearning és a blended learning fogalma, ami független a törvényi meghatározástól, és a piaci környezetből átvett módszertani fogalmat értjük alatta.

\section{A távoktatás}

A társadalmi és gazdasági változások korunkban egyre inkább szükségessé teszik az oktatási rendszer napra kész átalakítását. A felsőoktatásban mára már elterjedt és bevett módszer a távoktatás alkalmazása. A középfokú oktatás keretein belül a felnőttoktatásban és felnőttképzésben is egyre népszerúbbé válik ez az oktatási forma, hiszen sok új szakma születik, nő a szakmák iránti kereslet, és az érettségivel nem rendelkező, de azt megszerezni kívánó felnőtt korú tanulók is szívesen veszik igénybe e képzési formát. A távoktatás különösen kedvelt a magánszervezésű szakiskolákban, de az államilag is támogatott felsőfokú szakképzésben is egyre inkább bevett gyakorlattá válik a távoktatásos kurzusok szervezése. Ahogy Kovács Ilma fogalmaz: „A távoktatás nem akar a nappali oktatás helyére lépni, de új oktatási formaként a távoktatás a hagyományos oktatás mellett igyekszik részt venni az egész életen át tartó tanulás folyamatában." ${ }^{1} \mathrm{Az}$ információs társadalomban az

\footnotetext{
${ }^{1}$ Kovács Ilma: Új út az oktatásban? BKE FKI, Budapest., 1997. 10.o.
} 
internet által nyújtott technikai háttér biztos alapot nyújt ennek a képzési formának, hiszen megszűnik a tér- és időbeli kötöttség a tanulási folyamat során.

A tanulási környezet nem más, mint a tanulás külső feltételeinek összessége. A hagyományos jelenléti oktatásban a tevékenység két nagy egységre oszlik: az egyik maga a tanórai foglalkozás, a másik az otthoni, egyedül végzett felkészülés. Az IKT eszközök alkalmazása azonban megváltoztatta ezt a gyakorlatot. Szinte mindenhol belép új elemként az önálló tanulást segíto "távirányításos” szakasz, ami tulajdonképpen egy "tanár nélküli” állomás a tanulás folyamatában. Ebben az esetben a diák önállóan kezd az anyag feldolgozásába, ami többnyire azt jelenti, hogy utánanéz az interneten. A számítógépek megjelenése és az internet használata változatosabbá tette az oktatás színtereit. Így mára az alábbi környezeteket különböztetjük meg egymástól:

- kontakt oktatási tevékenység: Ekkor a tanár és a diák egy időben, egy helyen tartózkodik, a tanulási folyamat zárt környezetben történik. Használhatnak IKT eszközöket (pl. digitális tábla stb.), de nincs hálózati kapcsolat. Személyes kontakt kapcsolat áll fenn a tanuló és tanára között.

- online eszközökkel támogatott környezet: a kontakt környezethez képest itt már csatlakoznak a hálózatra, az internet fontos kommunikációs csatorna. Ez lehet gépteremben, de vannak olyan országok, ahol a tanulók egyéni eszközeiket használják.

- blended learning környezet: más néven komplex vagy hibrid környezet. Lényege, hogy a kontakt órák mellett megjelenik az online tevékenység. Ez változatosságot eredményez az oktatásban, egyszerre valósul meg a hagyományos órák és az IKT eszközök segítségével történő egyéni tanulás. Változatos módszereket biztosít a hatékonyabb tanulás érdekében.

- a távoktatás mint oktatási környezet: a tanulás jelentős része egyéni környezetben, mára egyre inkább online térben zajlik, bár vannak személyes konzultációk. Fontos a módszertani alaposság, mivel az oktatócsomag közzététele önmagában nem elégséges, a tanuló és a tanítók közötti kapcsolatot, valamint a tanuló és az intézmény közötti kapcsolatot szervezni kell, ezért a facilitáció nagy hangsúlyt kap. Emellett az oktatásszervezés is fontos része a folyamatnak, mivel a távoktatás hatékonyságát nagyban befolyásolja. ${ }^{2}$

\section{Távoktatás a magyar köznevelésben}

Magyarország Alaptörvényének XI. cikke így fogalmaz: „(1) Minden magyar állampolgárnak joga van a múvelődéshez." Ez az általános irányelv valósul meg a magyar köznevelésben. Ezért kiemelt helyen szerepel a képzettséggel nem rendelkezők szakmához juttatása, a felzárkóztatás. „Magyarországon évente átlagosan 5-7 ezerre tehető az alapfokról a középfokra való átmenet időszakában a képzésből kimaradók, lemorzsolódók száma. Felmérések (statisztikai adatok) szerint a 2013/2014. tanévben - a tanköteles életkor leszállítását követően már - kb. 14-15 ezer tanuló maradt ki a köznevelési rendszerből.."3

\footnotetext{
2. http://tavoktatas-2013.blogspot.hu/2013/02/igy-kezdodott-tavoktatas-es-elearning.html Letöltés: 2015. 03.08.

${ }^{3}$ http://www.mszoe.hu/index.php?oldal=alap.php\&fid=155\&id=372 Letöltés ideje: 2014 . 10.08.
} 
Mivel a lemorzsolódók száma nagy, feltétlenül fontos e számarány drasztikus csökkentése, a kallódó gyermekek és felnőttek esélyhez való juttatása. Az Európai Unió 2020-ra kitúzött öt stratégiai céljának egyike - amelyet hazánk is célul tűzött ki -, hogy az évtized végére 10\%nál kevesebb legyen azon 18-24 éves fiatalok aránya, akiknek nincs középszintű végzettsége, azaz akik szinte teljesen esélytelenül lépnek be a munkaerőpiacra" ${ }^{44}$. Ez a felnőttoktatás számára kiemelt szerepet biztosít. A felnőttoktatásban meglévő hagyományos esti és levelező képzés mellett a távoktatás is megjelenik az oktatási palettán. A 2011. évi CXC. törvény a nemzeti köznevelésről így rendelkezik a felnőttoktatás keretein belül folyó távoktatásról:

60. $\S(8)$ Más sajátos munkarend szerint is folyhat az oktatás, ha a tanulónak tanórai foglalkozáson egyáltalán nem kell részt vennie, továbbá, ha a tanórai foglalkozások száma nem éri el a levelező oktatásra meghatározott óraszámot. Más sajátos munkarend szerint folyik a felnőttoktatás különösen a távoktatási formában.

A 110/2012 (VI.4.) Korm.rendelet a Nemzeti alaptanterv kiadásáról, bevezetéséről és alkalmazásáról feladatául tűzte ki a „tanuláshoz és munkához szükséges képességek, készségek, ismeretek, attitűdök együttes fejlesztését" Szándéka szerint az elsajátított tudásnak „értékállónak és a kor igényinek megfelelőnek” kell lennie. A kulcskompetenciák között pedig szerepel a digitális kompetencia. A távoktatási forma tehát minden szinten kielégíti a köznevelés elvárásait.

\section{A vizsgálat körülményei}

Kutatásom során először on-line kérdőíves felmérést készítettem a Kérdőívem.hu internetes portálon a távoktatási intézmények vezetői és a távoktatásban oktató pedagógusok számára. Mivel kevés válassz érkezett, a kérdőíves megkeresés mellett interjúkat is készítettem. Az interjúkészítés során figyeltem arra, hogy különböző típusú oktatási formákat (digitális középiskola, blended learning, hagyományos távoktatási forma) mutassak be, és a budapesti helyszínek mellett vidékre is eljussak. Felmérésem szerint többen távoktatásként tüntetik fel képzésüket, noha e-learningről vagy blended learningről van szó. Ezért az első tapasztalatom az volt, hogy a távoktatás elég tág fogalom a magyar köznevelési rendszerben.

Az interjúkban bemutatott intézmények a következők voltak:

- 2014. november 7-én a kecskeméti Németh László Gimnáziumban jártam, ahol az intézményegység-vezetővel készítettem interjút a digitális középiskoláról.

- 2014. december 01-én jártam a budapesti Leövey Klára Gimnáziumban, ahol szintén müködik digitális középiskola, ott is az intézményegység-vezetővel készítettem interjút.

- 2014. december 02-án a Pestszentlőrinc-Pestszentimrei Felnőttek Gimnáziumában jártam, ahol az intézményvezető asszonnyal készítettem interjút az intézményükben folyó levelező távoktatásról.

\footnotetext{
${ }^{4}$ http://www.mszoe.hu/index.php?oldal=alap.php\&id=120 Letöltés ideje: 2014. 10.08.
} 


\section{A felvetett hipotézisek és az azokra kapott válaszok}

Dolgozatomban három hipotézist állítottam fel a szakirodalom és egyéni tapasztalataim segítségével ${ }^{5}$ :

- A távoktatás a piac körülményeihez alkalmazkodik, ezért a hagyományos tanári szerepkör megváltozik, csökken az oktatói szabadság, nő a menedzsment és az intézményvezetés szerepe a folyamatokban.

- A távoktatás IKT eszközei még fejlesztésre szorulnak, noha a tanulói igények -főleg a fiatalabb korosztály esetében- ennek erősítését szorgalmazzák.

- A távoktatásban tanulók száma nő, de még mindig jelentős a lemorzsolódás, amit a vezetőnek figyelembe kell vennie.

Összegezve megállapítható, hogy az első hipotézis felvetései csak részben igazolódtak be. Azt a kérdést, hogy a távoktatás piaci szolgáltatás-e, a megkérdezettek általában elutasították. $A$ kérdőív eredményeként a felmérésben részt vevő intézményvezetők az ötös értékü Likertskálán 2,64\%-os átlagot adtak, ami ha nem is elutasítás, de az el nem fogadás egyértelmú jele. A pedagógusok válasza elfogadóbb szemléletet tükrözött, ők 3,43\%-ban értelek egyet ezzel a feltételezéssel. Az interjú alanyai általában elutasították ezt a feltételezést. Az egyik intézményvezető szavaival szeretném felhívni erre a figyelmet: „az esélyegyenlőség megteremtése érdekében a piac követelményeitől függetleníteni kell a távoktatást a köznevelésben".

Abban sokan egyetértenek ugyanakkor, hogy a hagyományos tanári szerepkör átalakul a távoktatás rendszerében. Ehhez pedig szemléletváltásra van szükség. A kollégáknak az új rendszerben alkalmazkodni kell például az új, digitális szemlélethez. Ezért képzéseken vesznek részt, ahogy arról a digitális középiskola és a Cisco Hálózati Akadémia résztvevői beszámoltak. A hagyományos oktatásból ismert szerepkörök mellett felvállalják a távoktatás új kihívásait, oktatóanyagokat készítenek, tutorálnak, részt vesznek a szervezésben. Ahogy a kérdőívem rámutatott, néhány esettől eltekintve nem nő a köznevelésben a nem pedagógiai szerepet ellátók száma. Tehát a legtöbb távoktatásban megjelenő feladat a pedagógus vállát nyomja.

Azt viszont a válaszadók elfogadják, hogy a távoktatásban nő a menedzsment és a vezetés szerepe, a pedagógusra hatással vannak a körülmények. Ilyen például a szervezés lebonyolítása, ahol nagyban kiveszik részüket a kollégák. A rendszer tehát a pedagógusok rugalmasságára és munkabírására épül.

A válaszokból megállapítható, hogy a második hipotézis a korosztályi összetétellel kapcsolatos elvárásaim kivételével beigazolódott. Annak ellenére, hogy a korosztályi összetétel vegyes képet mutat, úgy tűnik, hogy egységes az igény tanulói részről az IKT eszközök intenzív használatára. Ez pedig vitatatatlanul azzal kell járjon, hogy a felnőttoktatási intézmények technikai hátterét fejleszteni, karban tartani kell, ehhez pedig megfelelő forrásokat kell hozzárendelni.

Összegezve a harmadik hipotézisre kapott válaszokat, elmondhatom, hogy nem mutatható ki egyértelmúen, hogy nő a távoktatásban tanulók létszáma a köznevelés intézményeiben. Azonban mindenhol probléma a felnőttoktatásban tanulók nagyarányú lemorzsolódása.

\footnotetext{
${ }^{5}$ A szakirodalomban nagy segítséget nyújtott Kovács Ilma már említett múve: Új út az oktatásban
} 


\section{A vizsgálat következtetései}

Ahogy fentebb megállapítottam, a távoktatás a magyar köznevelésben inkább módszerként jelenik meg, és nincs egyértelmű fogalom arra, a gyakorlatban mit értenek távoktatás alatt (e-learning, blended learning és egyéb módszerek). Elvárásaimmal ellentétben jóval kevesebb felnőttoktatási intézmény szánja rá magát a távoktatás törvényi keretek között megalkotott képzési formájának bevezetésére. Számos intézménnyel beszéltem telefonon, ahol a KIR adminisztrációs rendszerben jelölik ugyan a más sajátos munkarendet, valójában azonban nem oktatnak ebben a képzési formában.

Kutatásaim során több telefonbeszélgetést is folytattam, így jutottam el egy nevét mellőzni kívánó intézményhez, ahol érdekes felvilágosítást kaptam a nyírségi és szabolcsi térség helyzetéről. Mivel számos oktatási intézményben érdekeltek, ahol felnőttoktatás is folyik, szerettem volna megtudni, hogyan látják e régió jövőjét a távoktatásban. Sajnálattal számoltak be arról, hogy számos helyen olyan nagy a mélyszegénység, hogy sem számítógép, sem internet elérési lehetőség sincs sokaknál. Erős ugyanakkor a szociokulturális hátrány számos esetben, amit szintén nehéz leküzdeni. Ezekben az esetekben távoktatásról beszélni szinte lehetetlen. Ezeknek a tanulóknak „fogni kell a kezét”, hiszen nem rendelkeznek megfelelő tanulási kultúrával vagy munkamorállal. Tehát maga a társadalmi környezet is erősen befolyásolja, hol érdemes távoktatással foglalkozni és hol nem. A nagyvárosok és jobb módú régiók inkább alkalmasak a távoktatás megteremtésére. De akkor el kell gondolkodni azon, hogy a távoktatás valóban távoktatás-e a magyar köznevelésben? Hiszen a távoktatásban el kell túnnie a térbeli korlátoknak, és ha valóban a piac lenne meghatározó, akkor csak annyi kell, hogy az számítson, a tanuló megkapja-e az ár-érték arányban az általa elvárt szolgáltatást. Ugyanakkor érdemes lenne olyan tanulói felmérést is végezni, ami azt vizsgálja, hogy a tanulónál mennyire szempont az intézmény kiválasztásánál a lakóhelyéhez vagy egyéb életkörülményeihez közel eső iskola melletti voksolás.

Kiknek ajánlott a távoktatásban tanulóként részt venni? Mivel a távoktatás megfelelő oktatócsomagok és szaktanári útmutató alapján is elsősorban önálló, egyéni tanulást feltételez, ezért fontos a megfelelő tanulási stratégia megléte vagy kialakítása. Emellett biztos számítógép-felhasználói ismerettel kell rendelkeznie, továbbá otthoni számítógéppel és internet kapcsolattal felszerelt háztartásból kell érkezzen. Ezért nehézkes bizonyos hátrányos helyzetű régiókban vagy egyéneknél megvalósítani ezt az oktatási formát. Ugyanakkor azt se felejtsük el, hogy a felnőttoktatásban a távoktatás csak egy lehetséges módszer, de nem az egyetlen megoldás. Kutatásaim nem igazolták egyértelmúen az IKT technikák alkalmazásában megjelenő generációs különbséget, de azt igen, hogy a géphasználatban erős eltérések vannak, ami sokaknál tovább nehezíti a digitális környezetben való eligazodást. Ugyanakkor mára a munka világában való részvétel esetén, de egy egyszerú számla befizetésénél is fontos a digitális kompetencia megléte. Tehát egy jól megtervezett és előkészített távoktatási környezet erősítené a felnőtt társadalom hátrányos helyzetű tagjainak digitális ismereteit. Hiszen ahogy Kovács Andrea említette interjújában, van, aki azért iratkozik be képzésükre, hogy megfelelő számítógépes ismeretekre tegyen szert, amit élete más területein is kamatoztathat. Mivel a távoktatásban nagy a lemorzsolódás - ahogy egyébként a felnőttoktatásban általában -, fontos, hogy maga a rendszer olyan keretet adjon, ami csökkenti az iskolát újból elhagyók számát. Ahogy Nagy Gergő Adrián fogalmazott, a felnőttoktatásban tanulók léthelyzete sokszor olyan 
bizonytalan, hogy változás esetén inkább az iskolát hagyják abba. Mivel az érettségihez való jutás feltétele általában négy év, ez a felnőtt tanulók számára túl hosszú időszak, hiszen munkájukban, magánéletükben ennyi idő alatt jelentős változások állhatnak be. Tehát ha azt feltételezzük, hogy a távoktatásban tanulók képesek az önálló egyéni tanulásra, mert megvan bennük a tanulási kompetencia, akkor távoktatás esetén is felmerülhet az igény a szakiskolások középiskolája programhoz hasonló időintervallumra. Úgy gondolom, hogy a távoktatásban részt vevő tanulók esetében nyugodtan csökkenthető a tanulmányi idő, ha más esetekben ugyanezt engedélyezzük. Ez a rendszer részéről teremtene olyan segítséget, ami vonzóbbá tehetné a távoktatást a köznevelésben az érettségihez jutás esetében. Az „időnyereséget” pedig szakképzési ráépülésre lehetne fordítani olyan szakmák esetében, ahol engedélyezett a távoktatási forma. Ugyanakkor a szakképzésben is érdemes elgondolkodni, hol, mely területeken nyerhetne nagyobb létjogosultságot a távoktatás. Az a tanuló ugyanis, aki e-learninges környezetben, távoktatási módszerek segítségével el tudott sajátítani egy érettségit, akár át is képezheti magát vagy megszerezheti első szakmáját a már ismert digitális környezetben. Ezzel pedig akár a hátrányos régiók felzárkóztatását is elő lehet segíteni.

Ki tanítson a távoktatásban? Szerencsére a felmérés azt igazolta, hogy az tanít távoktatásban, aki arra alkalmas személy. Mivel itt rugalmasabbnak kell lenni, ahogy dr. Grünvald Mária fogalmazott, ez sokszor huszonnégy órás szolgálat, aki nem alkalmas erre a szerepre, az vagy nem vállalja a feladatot, ahogy ezt a felmérésben példa is igazolta, vagy lemorzsolódik maga is.

A távoktatás alapvető feltétele a megfelelő IKT ellátottság. Ez követelmény az intézménytől, elvárás a tanulótól. Alapvetően az iskolák biztosítják a tanulók számára a számítógéphez való hozzáférést, a digitális iskolákat egyenesen kötelezik is erre, de az az általános tapasztalat, hogy aki nem rendelkezik e-mail fiókkal, az például nagyobb eséllyel morzsolódik le, hiszen a rendszer számára utólérhetetlen. Ha pedig rendelkezik e-mail címmel, akkor vagy otthoni vagy egyéb (munkahelyi, baráti stb.) környezetben van lehetősége az e-learninges tananyagok letöltésére, tanulmányozására, az iskola életében való részvételre (hírfórum, adminisztráció stb.). Tehát az IKT-környezet megléte szűrő a távoktatást választók számára. Intézményi szinten pedig fontos a megfelelő digitális környezet kialakítása, de annak fenntartása ugyanolyan fontos. Mivel az informatika az egyik legdinamikusabban fejlődő ágazat, a gépek négy-öt év alatt elévülnek, amortizálódnak. Tehát az IKT eszköz beszerzése nem egyszeri anyagi beruházás, hanem folyamatos karbantartást igénylő feladat. Ahogy a felmérés mutatja, ezen a területen van még mit fejlődni.

\section{Javaslatok a köznevelésben megjelenő távoktatás számára}

- Érdemes elgondolkodni, vajon a távoktatás köznevelésben betöltött szerepe alapján piaci résztvevőként kell-e értelmezni a távoktatást. Mivel az állami fenntartású intézmények számára konkurenciát jelentenek a magánkézben lévő intézmények, ahol sokszor alacsony színvonalú oktatómunka folyik, fontos lenne, hogy az arra alkalmatlan iskolákat szűrjék ki a rendszerből.

- Készítsenek a távoktatás számára konkrét kerettantervet, ami azt eredményezné, hogy a távoktatás bekerülne a tantárgyfelosztásba. 
- Ezzel párhuzamosan az oktatócsomagokat is központilag állítsák elő ugyanúgy, mint a tankönyveket.

- Az intézmények IKT ellátottságát pedig központi pályázatokkal támogassák azon intézmények számára, akik távoktatásos képzési formát is fenntartanak.

- A tanulmányi időt hasonló módon lehetne csökkenteni, mint a Kerettanterv a szakiskolát végzettek középiskolája esetében. (A kerettantervek kiadásának és jóváhagyásának rendjéről szóló 51/2012. (XII. 21.) számú EMMI rendelet 13. sz. melléklete, ami Megjelent a 34/2014. (IV. 29.) EMMI rendelet 11. mellékleteként)

Ha abból a feltételezésből indulunk ki, hogy a távoktatásban részt vevő tanulótól jóval nagyobb önállóságot, tanulói aktivitást várunk el, akkor ez a program megfelel az elvárásoknak. Mivel a távoktatást választó tanulók zöme azért választja ezt a képzési formát, mert valamilyen korlátok nem teszik lehetővé az iskolai térben való „folyamatos” jelenlétet, valószínúleg az idő is korlátozó tényező számukra. A mai változó világban a változások gyors követése elengedhetetlen feltétel a munka világában való sikeres szereplésnél. $A z, a k i$ gyorsabban tudja átképezni magát, hamarabb jut az előnyt biztosító „papírhoz”, jobb pozícióba tudja hozni magát a többiekkel szemben. Ugyanakkor az esélyegyenlőség megteremtésének is feltétele, hogy a hátrányos helyzetben lévők szintén minél hamarabb megszerezzék az érettségit vagy az OKJ-s szakképesítést.

A javasolt rendszer a következő modulokon nyugszik:

- A bevezető rész kompetenciafejlesztés lenne. Ez megfelel a Nemzeti alaptantervben meghatározott „tanulás tanítása” fejlesztési területnek, hiszen a távoktatásos vagy elearninges keretek között zajló tanulmányok elvégzésénél elengedhetetlen. Ugyanakkor szintén a Nemzeti alaptantervben szereplő digitális kompetencia és a hatékony, önálló tanulás kompetenciájának fejlesztése a fő cél, hiszen ezeken a területeken már a program elejétől kezdve eredményesnek kell lennie a tanulónak. Főként olyan informatikai alapismeretek megszerzése a cél, amelyek megfelelő hátteret biztosítanak a sikeres érettségi vagy szakma távoktatási környezetben történő megszerzéséhez. A modul végén szintvizsgát kell tenni a sikeres továbblépéshez. Ez a vizsga azok számára, akik megfelelő informatikai háttérrel rendelkeznek, és képesek az önálló tanulásra, különbözeti vizsgával megszerezhető lenne. A bevezető képzés hangsúlyozottan jelenléti konzultáció keretében zajlana, hiszen itt kell megszerezni azokat a képességeket és jártasságokat, amiken a későbbi kurzusok elvégzése alapul. A képzés a Moodle rendszerhez hasonló (vagy akár magán a Moodle felületén) felületen zajlana. Így a jelenléti konzultációt kiegészítené a digitális felület megismerését szolgáló digitális konzultáció. Ugyanakkor a feladatok leadása, az oktatócsomagok letöltése már a kezdetektől webes felületen zajlana. Így az önálló tanulás és problémamegoldás is fejleszthető lenne a tanulóknál.

- $A z$, aki nem rendelkezik érettségivel, a második modulban vesz részt. Itt a cél az érettségi megszerzése. A felépítése négy féléves lenne, ahol az első félév a 9. évfolyam anyagára épülne, a második a 10. évfolyaméra, a harmadik a 11. évfolyaméra, a negyedik a 12. évfolyaméra. Mivel a cél az érettségi megszerzése, ezért a kötelezően oktatandó tantárgyak a szakiskolások középiskolája számára készített tantárgyakéval egyeznének meg: magyar nyelv és irodalom, idegen nyelv, 
matematika, történelem, társadalmi és állampolgári ismeretek, természetismeret, informatika. Mivel az első modulban tantárgyi szinten "csak” informatikát tanultak, és a képzés során végig tanulták is két éven keresztül, ezért a választott érettségi tantárgy e program esetében determináltan az informatika lenne. Ez hasznos a munkaerőpiacon történő elhelyezkedés esetén. Az egyes évfolyamokon a továbbhaladás osztályozóvizsgák keretében zajlana minden évfolyam elvégzése esetén. A konzultációk során pedig ötvözni kell a digitális és a jelenléti konzultációt, ahogy azt a digitális középiskolák is teszik. Mivel távoktatás esetében a konzultációs jelenlét nem kötelező, csak ajánlott, ezért ez a külföldön élők számára is előnyös, hiszen a tanuló az on-line konzultációba bárhonnan be tud kapcsolódni, ugyanakkor személyes kérdéseivel bármikor felkeresheti szaktanárát.

- A harmadik modul a távoktatás keretében oktatható szakmák számára készült. Ide azok az érettségivel rendelkező tanulók jelentkezhetnek, akik az első modult elvégezték, vagy letették belőle a különbözeti vizsgát. Az a tanuló, aki letette ebben a rendszerben az érettségit, az is jogosult ebben a modulban való részvételre.

- Ebben a rendszerben az előny, hogy aki bekapcsolódik, körülbelül ugyanannyi idő alatt szerezhet érettségit és szakmát, mint amennyi idő alatt hagyományos keretek között érettségit szerezne. Természetesen erre nem minden felnőttoktatásban tanuló alkalmas, de ugyanilyen szürő a már meglévő rendszerben a szakiskolások számára készített kétéves program, ami az érettségi megszerzését célozza. Az idő haladtával egyre nő azon fiatalok száma, akik már megfelelő informatikai háttérrel rendelkeznek. Nekik a tanulási kultúrájukat kell erősíteni, erre pedig jó lehet az első féléves alapozó kurzus. De talán a hátrányos helyzetű, de tehetséges tanulókat is segítheti, hogy minél hamarabb jussanak érettségihez és szakmához. Első szakma megszerzése esetén pedig előny az ingyenesség mellett a hatékonyság. Mivel azok a tanulók, akik felnőttoktatásban tanulnak, zömében dolgoznak, számukra kecsegtető lehet ezen lehetőségek jelenléte az „oktatás piacán”. Nem minden tanuló alkalmas a távoktatási keretek közötti tanulásra, de aki igen, annak nagy nyereség a rendszer rugalmassága. Felnőttoktatásban tanítóként pedig tisztában vagyok vele, hogy igen nagy a lemorzsolódás tanulóink körében. Nincsenek illúzióim, hogy hatalmas tömegek tudnak ilyen keretek között végezni, de ugyanúgy, ahogy a nappali képzés figyelembe veszi a tehetséget, nálunk, a felnőttoktatásban is kell olyan esélyt és lehetőséget teremteni, hogy a tehetséges, de későn érő, vagy korábban lehetőségekkel nem rendelkező tanuló is megtalálja a maga számára ideális képzési formát.

Ennek a rendszernek az az előnye, hogy az érettségi megszerzése mellett gondol a szakma iránt érdeklődőkre is, és aki ebben a keretrendszerben szerez érettségit, és jártasságot e rendszer használatában, az szakmát is tud elsajátítani e moduláris rendszerben.

\section{Összefoglalás}

A távoktatás valóban új út az oktatásban, de nem az egyetlen járható út. Vizsgálataim során rá kellett döbbennem, hogy a szakirodalomban sok az illúzió a távoktatással kapcsolatban. 
Ideális diákból és ideális helyzetből indul ki. De a felnőttoktatásban sajnos ez az idealizmus nem érvényesül a köznevelésben. Tehetséges egyetemistáknál, felsőfokú szakirányú továbbképzésnél igen alkalmas a módszer, de a középfokú oktatásban csak egy bizonyos szegmens számára adott a lehetőség. De ahogy az előző fejezetben írtam, ha a felnőttoktatást a nappali képzéssel egyenrangú oktatási formának tekintjük, akkor itt is szükség van a tehetség esélyhez juttatására. A tehetség nálunk nem OKTV győzelmet jelent, hanem sikeres érettségit vagy az adott szakma elsajátítását, a tanulásba vetett hit visszaadását, az önbecsülés megerősítését. Siker az is, ha a felnőtt tanuló rövidebb időbefektetéssel jut el a kívánt bizonyítvány megszerzéséhez, ezáltal a szakmai élete továbblendül, jobb álláshoz és biztosabb jövedelemhez jut, ami rajta és a családján segít. Tehát ugyanazzal a mértékkel, mégis másként mérünk.

Még inkább rádöbbentem ugyanakkor az esélyegyenlőség fontosságára, hiszen a távoktatás módszere világosan rámutatott arra, milyen nagy a szakadék az ország régiói és az egyes emberek lehetőségei között. Az e-learning oktatás jól múködik egy elit budapesti informatikai szakközépiskolában, de más képet mutat a távoktatás a mélyszegény rétegből jövők esetében. Amikor a fejlesztési javaslatomat átgondoltam, ezért volt számomra fontos az általam elgondolt moduláris rendszer első lépcsőfoka, ami lehetőség a hátrányok leküzdésére. Arra, hogy a távoktatás szélesebb körök számára legyen új út az oktatásban. Hiszen a munka világában és egyéni életünkben már szinte mindenkit utolér a digitális kihívás, a munkanélküliség erőteljes megléte pedig magával hozza az átképzések szükségességét.

Írásomban igyekeztem átfogó képet adni a magyarországi köznevelési rendszer távoktatási lehetőségeiről. Ezúton szeretném megköszönni mindazok segítségét, akik az interjúk elkészítésében részt vettek. Munkám elkészítése sokat segített saját szakterületemen is, ötleteket, módszereket adva további munkámhoz. Köszönettel tartozom konzulensemnek, dr. Janza Károlynénak, aki áldozatos munkával segítette jelen írás alapját képező szakdolgozatom elkészülését.

\section{Felhasznált irodalom}

- Arató Gergely: A felnőttképzés szerepe az új Európa 2020 stratégiában/ In: Tudás menedzsment 2011. október XII. évfolyam 2. szám 3-11.p./ http://old.feek.pte.hu/tudasmenedzsment/full/122szam.pdf Letölté s ideje: 2014. 12.01.

- Bajusz Klára: Iskolarendszerű felnőttoktatás az ezredfordulón. PTE FEEK Pécs 2005., 208 p

- Breiner Ildikó: Távoktatás és távmunka, e-learning és e-work In: http://www.hrportal.hu/hr/tavoktatas-es-tavmunka;-e-learning-es-e-work20071009.html Letöltés ideje: 2014. 10. 01.

- Csoma Gyula: A távoktatás „mint olyan” és mint a levelező oktatás reformja. Új Pedagógiai Szemle, 1992/9., 43-54 p

- Csoma Gyula: A felnőttoktatás rendeltetése. Új Pedagógiai Szemle, 1995/2. 3-15 p 
- Csoma Gyula - Lada László: A távoktatás lehetőségei a felnőttoktatásban. in: http://www.ofi.hu/tudastar/problemak-kerdesek/tavoktatas-lehetosegei Letöltés: 2015. február 01.

- Európa és a Globális Információs Társadalom, Az Európai Unió Tanácsának készült Bangemann jelentés, A korfui európai csúcsértekezlet határozata, Bledi közép-európai miniszteri tanácskozás dokumentumai, 1994. júniius-július, A CORDIS Fokus 1994. július 15i melléklete alapján az összeállítás az OMFB gondozásában készült 1.0 verzió http://www.mek.iif.hu/porta/szint/muszaki/szamtech/wan/hatasok/bangemn.hun Letöltés: 2014. december 01.

- Felnőttoktatási Kislexikon (Kossuth Kiadó, Budapest, 1987, Főszerk.: Csiby Sándor), 265 p

- Felvégi Emese: Távoktatás, e-learning és nyitott oktatás Anglia, az Egyesült Államok, Finnország, Németország, Svédország oktatási rendszerében, in: Új Pedagógiai Szemle, 2005 decemberében, 92-99 $p$

- Forgó Sándor: Az eLearning fogalma. In: Hutter Ottó - Magyar Gábor - Mlinarics József: E-LEARNING 2005 (eLearning kézikönyv), Műszaki Könyvkiadó, 2005., 136 p

- Főző Attila László: Szinkrón és asznkrón kommunikáció IKT alapú oktatási projektekben in: http://www.ofi.hu/tudastar/szinkron-aszinkron Letöltés: 2014. december 29.

- Hain Ferenc, Hutter Ottó, Kugler Judit: Az elektronikus eszközökkel támogatott tanulás (e-learning) mint lehetőség, Világosság, 2005. 2-3.sz., 3-23 p http://epa.oszk.hu/01200/01273/00021/pdf/20050530052007.pdf Letöltés: 2014. december 30.

- Dr. Hutter Ottó - Dr. Magyar Gábor - Dr. Mlinarics József: E-learning 2205, Műszaki Könyvkiadó, 2005, 14 p

- Illyné Újvári Irén - Szabó József - Szentpéteri Zsolt -Szilágyi Ágnes - Zoltai Márta: Segítség! Tanulok!? Kézikönyv nyitott- és távoktatásban tanulóknak Számalk, Bp., 1998.

- Imets Márta: Tutori munka a távoktatásos gimnáziumi felnőttképzésben in: Új Pedagógiai Szemle $57 . \quad$ évf. 12.sz. 123-127. p http://epa.oszk.hu/00000/00035/00119/2007-12-mu-Imets-Tutori.html Letöltés: 2014. 10.02.

- Komenczi Bertalan: Didaktika elektromagna? Az e-learning virtuális valóságai. in: Új Pedagógiai Szemle $2004 . \quad$ november. http://epa.oszk.hu/00000/00035/00086/2004-11-ta-Komenczi-Didaktika.html

- Kovács IIma: Új út az oktatásban? BKE FKI, Bp., 1997, 274 p

- Kovács IIma: Távoktatástól távoktatásig. Válogatott tanulmányok, cikkek és előadások gyújteménye. Budapest, 2006 kn, 364 p

- Kovács Ilma: Távoktatás Franciaországban 1993-1994, Nemzeti Tankönyvkiadó, Bp., 1995., $356 \mathrm{p}$ 
- Kovács Ilma: Az elektronikus tanulásról a 21. század első éveiben. Magánkiadás, Budapest, 2011., $274 \mathrm{p}$

- Walter F. Kugemann: Megtanulok tanulni, Gondolat Kiadó, Bp., 1981., 309 p

- Lajos Tamás, Szúcs András: A távoktatás helyzete és fejlesztésének távlatai Magyarországon. A Magyar Nemzeti Távoktatási Tanács Kiadványa, Bp., 1993.

- Magyar Miklós: A tanulás = élettevékenység A Csokonai Vitéz Mihály Tanítóképző Főiskolakiadványai, Tankönyvsorozat 9. kötet, Kaposvár. 1999., 70p

- Maróti Andor: Mi a távoktatás? A Nemzeti Távoktatási Tanács kiadványai 1. Bp., 1992., $63 \mathrm{p}$

- Mayer József: A tanulás kora, Felnőttoktatási Akadémia, Gyula, 2002, 16-19. p

- MultiMédia az Oktatásban 2007 Konferencia Budapesti Múszaki Főiskola, 2007. augusztus 23-24.; $\quad$ http://uniobuda.hu/conferences/multimedia2007/36 MakoBanhidyne.pdf Letöltés: 2014. december 29.

- Ollé János: A felelősség elbújt a pókhálós sarokban in: http://blog.ollejanos.hu/2013/01/27/a-felelosseg-elbujt-a-pokhalos-sarokban/ Letöltés: 2015. 02. 08.

- Ollé János: Oktatásszervezés és tanulástámogatás, az oktatási folyamat szabályozása. http://bit.ly/11XaQ9w Letöltés: 2015. január 20.

- Ollé János - Papp-Danka Adrienn - Lévai Dóra - Tóth-Mózer Szilvia - Virányi Anita: Oktatásinformatikai módszerek. Tanítás és tanulás az információs társadalomban. ELTE Eötvös Kiadó, Budapest, 2013

- Selinger Sándor: A távoktatásról mint oktatási alternatíváról. in: Korunk 2000 szeptember http://korunk.org/?q=node/6385 - Korunk 2000 Letöltés ideje: 2015. február 16.

- Sevidiné Balassa Ildikó: A nyitott, távoktatási rendszer (2. sz. munkafüzet) Kaposvár Keszthely, 1999., 68-70. p

- Dr. Szabó József: A távoktatás lehetőségei az iskolarendszerű felnőttoktatásban, Szent István Egyetem, Gödöllő in: http://www.ofi.hu/tudastar/tanulaskora/tavoktatas-lehetosegei Letöltés: 2015. 01. 02.

- Sulyok Tamás: Távoktatás (előadásvázlat) PTE TTK FEEFI, 2001, Pécs, 25 p

- Sz. Molnár Anna: A tanuló felnőtt in: http://www.diral.hu/publikaciok/A tanul\%C3\%B3 feln\%C5\%91tt.pdf Letöltés: 2015. 03.06 .

- Szegediné Lengyel Piroska: Ötven éves a távoktatás? (Programozott oktatás és elearning - programozott könyv és e-könyv.) in: Hadmérnök, V. évf. 3. szám, 2010. szeptember http://hadmernok.hu/2010 3 szegedine.pdf Letöltés: 2015. január 13.

- Szilassy Margit: Távoktatás - gyerekeknek, felnőtteknek, mindenkinek! Köznevelés 1995/8. szám 
- Távoktatás Magyarországon 1970-1980, Tanulmánykötet Szerk.: Kovács Ilma, az OKKFT T/s-4 gondozásában, Budapest, 1992, $225 \mathrm{p}$

- Távoktatás: túl az első lépéseken. in: A Munkaadó Lapja 102. számában (2006. szeptember 14.) in: http://munkaugyilevelek.hu/2006/08-09/tavoktatas-tul-az-elsolepeseken/ Letöltés: 2015. 03. 06.

- Zrinszky László: Iskolaelméletek és iskolai élet. Okker Kiadó, 2000, 255 p

\section{Internetes letöltések:}

- http://hu.wikipedia.org/wiki/T\%C3\%A1voktat\%C3\%A1s Letöltés ideje: 2014. október 06. http://www.olcsokepzes.hu/index.php/ceguenkrol/tavoktatas Letöltés ideje: 2014. 10. 08.

http://epa.oszk.hu/00000/00035/00098/2005-12-iz-Felvegi-Tavoktatas.html Letöltés ideje: 2014. 10. 01.

- http://ujkep.net/fex.page:2010-01-

$14 \mathrm{Az}$ oktatas es neveles mint foglalkozas.xhtml Letöltés ideje: 2014. 10. 01.

- https://www.google.hu/?gws rd=ssl\#q=isdn Letöltés: 2014. 10. 02.

- http://www.mszoe.hu/index.php?oldal=alap.php\&id=120 Letöltés ideje: 2014 . 10.08.

- http://www.mszoe.hu/index.php?oldal=alap.php\&id=120 Letöltés ideje: 2014. 10.08.

- http://www.oktatas.hu/hivatali ugyek Letöltés: 2015. 01. 02.

- http://dp-tavoktato.felgimi.hu/?tavoktato Letöltés: 2014.12.14.

- Szinyei Merse Pál Gimnázium Pedagógiai Programja

- in: http://www.terezestigimi.hu/files/content/20/PP feln\%C5\%91tt 2014.pdf Letöltés: 2015. 02. 03.

- http://www.netacad.hu/hu/ciscohalozatiakademia Letöltés: 2015. 02.03

- http://www.netacad.hu/hu/kurzusok Letöltés: 2015.02. 03.

- http://hu.wikipedia.org/wiki/Moodle Letöltés: 2014. 12. 30.

- http://munkaugyilevelek.hu/2006/08-09/tavoktatas-tul-az-elso-lepeseken/ Letöltés: 2015. január 08.

\section{A témát érintö blogok:}

- http://tavoktatas-2013.blogspot.hu Letöltés: 2015. január 03.

- http://bevezetes-ikt-2012osz.blogspot.hu Letöltés: 2015. január 04. 


\section{Melléklet:}

\section{Melléklet: Az interjúk témakörei}

Interjúkészítésem során fő szempont volt, hogy az interjú és a kérdőív kérdései szinkronban legyenek egymással. Mivel különböző intézményekben készítettem mélyinterjút, a konkrét kérdések intézménytípusonként szerteágazóak és egyéniek voltak, de alapvetően az alábbi témaköröket érintették:

1. Az interjú alanyának rövid, személyes bemutatkozása

2. A látogatott felnőttoktatási intézmény bemutatása

3. A távoktatás megvalósulása az intézményben

4. Az intézmény IKT ellátottsága

5. A távoktatásban tanító kollégák bemutatása, milyen a viszonyuk a távoktatás rendszeréhez, az IKT eszközök használatához, szemléletük alkalmazkodik-e a távoktatás kihívásaihoz

6. Az oktatócsomagok készítésének módja, eljuttatása a tanulókhoz

7. A tanulókkal történő kapcsolattartás módja

8. A tutori és mentori rendszer múködtetése

9. A tanulók bemutatása:

- létszám,

- korosztályi összetétel,

- digitális szemlélet,

- lemorzsolódás 


\section{Kérdőív_vezetői}

Tisztelt Intézményvezető Úr/Hölgy!

Az alábbi kérdőív a köznevelési intézményekben folyó távoktatásra vonatkozik. A kérdőív kitöltésével szakdolgozati munkámat segíti. A téma sikeres feldolgozásához kérem, járuljon hozzá a kérdőív kitöltésével. Segítségét köszönöm!

\subsection{Az köznevelési intézmény típusa}

$\square$ általános iskola

$\square$ gimnázium

$\square$ szakközépiskola

$\square$ középiskola (gimnázium és szakközépiskola együtt)

$\square$ szakképző iskola (szakközépiskola és szakiskola együtt)

$\square$ többcélú intézmény

\subsection{Az intézmény székhelye}

Budapest

kisváros (50 000 fő alatt)

\subsection{Az intézmény fenntartója}

$\square$ állam

$$
\square \text { egyház }
$$

$\square$ alapítvány nagyváros (50 000 fö felett)

község

\subsection{A felnőttoktatás formája}

$\square$ önálló intézmény

$\square$ tagintézmény

intézményegység / tagozat

\subsection{A távoktatás képzési formája mellett jelen van a felnőttoktatásban}

esti munkarend

$\square$ levelező munkarend

$\square$ intenzív munkarend

\subsection{A felnőttoktatásban résztvevő tanulók létszáma}
$1-250$ fö
$\square 251-500$ fő
500 fő felett

\subsection{Ebből távoktatásban tanul}
$1-25 \%$
$2650 \%$
$51-75 \%$
$\square 76-100 \%$

1.8. Intézményvezetőként tapasztalja-e, hogy az utóbbi öt évben nőtt a távoktatás iránti igény intézményében?

$\square$ igen

nem 
1.9. A távoktatást megkezdők lemorzsolódási aránya az adott tanév végére hozzávetőleg
$\square 1-25 \%$
$\square 2650 \%$
$51-75 \%$
$\square 76-100 \%$

1.10. A tanulókkal történő kapcsolattartás módja (egyszerre több válasz is megjelölhető) $\square$ tutori rendszer múködtetésével $\square$ a moodle rendszer segítségével $\square$ postai levél útján $\square$ e-mail segítségével $\quad \square$ telefon $\quad \square$ skype $\quad \square$ videokonferencia $\square$ egyéb

1.11. Kérem, állítsa sorrendbe, mennyire ért egyet az alábbi állítással! 5-ös, amivel leginkább egyetért, 1-es, amivel legkevésbé.

$\square$ a távoktatásban a személyes kontaktus hiánya nagy arányú lemorzsolódáshoz vezet

$\square$ a távoktatás során a belülről motivált tanulók a legsikeresebbek

$\square$ a csoporttársaknak jelentős szerepük van a lemorzsolódás megakadályozásában

a tutor/mentor/konzulens segítségének jelentős szerepe van a lemorzsolódás megakadályozásában

$\square$ a felsőbbéves tanulók között kevesebb a lemorzsolódás

1.12. Kérem, jelölje 1-től 5-ig terjedő osztályozással, hogy mennyire ért egyet az alábbi állításokkal! 1=egyáltalán nem ért egyet, $\quad 5$ = teljesen egyetért

$\square$ a távoktatás piaci szolgáltatás

1.13. Kérem, jelölje 1-től 5-ig terjedő osztályozással, hogy mennyire ért egyet az alábbi állításokkal! 1=egyáltalán nem ért egyet, $\quad 5=$ teljesen egyetért

$\square$ a távoktatás költséghatékony képzési forma

1.14. Kérem, jelölje 1-től 5-ig terjedő osztályozással, hogy mennyire ért egyet az alábbi állításokkal! 1=egyáltalán nem ért egyet, $\quad 5=$ teljesen egyetért

$\square$ a köznevelési intézmények IKT ellátása kielégítő a távoktatás szervezése szempontjából

1.15. Kérem, jelölje 1-től 5-ig terjedő osztályozással, hogy mennyire ért egyet az alábbi állításokkal! 1=egyáltalán nem ért egyet, $\quad 5=$ teljesen egyetért

$\square$ a távoktatásban megvalósuló tér- és időbeli távolság jó szervezéssel könnyen áthidalható

1.16. Kérem, jelölje 1-től 5-ig terjedő osztályozással, hogy mennyire ért egyet az alábbi állításokkal! 1=egyáltalán nem ért egyet, $\quad 5=$ teljesen egyetért

a távoktatásban tanító kollégák megfelelő szemlélettel rendelkeznek, könnyen alkalmazkodnak az új kihívásokhoz 


\section{Kérdőív_pedagógus}

Tisztelt távoktatásban tanító Kolléga!

Az alábbi kérdőív a köznevelési intézményekben folyó távoktatásra vonatkozik. A kérdőív kitöltésével szakdolgozati munkámat segíti. A téma sikeres feldolgozásához kérem, járuljon hozzá a kérdőív kitöltésével. Segítségét köszönöm!

\subsection{Pedagógiai pályán eltöltöttem}
1-5 évet
5-15 évet
$\square 15$-30 évet
több, mint 30 évet

\subsection{A távoktatás mellett tanítok (egyszerre több válasz is elfogadható)}
$\square$ nappali $\quad \square$ esti
$\square$ levelezó
$\square$ intenzív képzésen.

\subsection{A távoktatásban}

$\square$ oktatóként $\quad \square$ tutorként $\quad \square$ tananyagfejesztőként tevékenykedem.

\subsection{Egészítse ki az alábbi állítást!}

Megítélésem szerint a távoktatásban tanulók

$$
\begin{aligned}
& \square \text { idősebb } \\
& \square \text { fiatalabb } \\
& \square \text { azonos korosztályi összetételűek }
\end{aligned}
$$

a más fenőttoktatási munkarandben tanulókkal.

\subsection{Egyetért-e az alábbi állításokkal?}

A távoktatás hatékony segítséget nyújthat a lemorzsolódás megakadályozásában.

$$
\square \text { igen } \quad \square \text { nem }
$$

\subsection{Egyetért-e az alábbi állításokkal?}

Jelenleg kevesebb tanuló veszi igénybe a távoktatást, mint az egyéb képzési formákat.

$\square$ igen $\quad \square$ nem

2.7. Kérem, jelölje 1-től 5-ig terjedő osztályozással, hogy mennyire ért egyet az alábbi állításokkal! 1=egyáltalán nem ért egyet, $\quad 5=$ teljesen egyetért

$\square$ a távoktatás piaci szolgáltatás

2.8. Kérem, jelölje 1-től 5-ig terjedő osztályozással, hogy mennyire ért egyet az alábbi állításokkal! 1=egyáltalán nem ért egyet, $\quad 5$ = teljesen egyetért

$\square$ a távoktatás költséghatékony képzési forma 
2.9. Kérem, jelölje 1-től 5-ig terjedő osztályozással, hogy mennyire ért egyet az alábbi állításokkal! 1=egyáltalán nem ért egyet, $\quad 5=$ teljesen egyetért

$\square$ a köznevelési intézmények IKT ellátása kielégítő a távoktatás szervezése szempontjából

2.10. Kérem, jelölje 1-től 5-ig terjedő osztályozással, hogy mennyire ért egyet az alábbi állításokkal! 1=egyáltalán nem ért egyet, $\quad 5$ = teljesen egyetért

$\square$ a távoktatásban megvalósuló tér- és időbeli távolság jó szervezéssel könnyen áthidalható

2.11. Kérem, jelölje 1-től 5-ig terjedő osztályozással, hogy mennyire ért egyet az alábbi állításokkal! 1=egyáltalán nem ért egyet, $\quad 5$ = teljesen egyetért

a távoktatásban tanító kollégák megfelelő szemlélettel rendelkeznek, könnyen alkalmazkodnak az új kihívásokhoz

\subsection{Az oktatócsomag elóállítása}

$\square$ Az iskolánkban dolgozó szaktanárok egyénileg készítik.

$\square$ Intézményünkre jellemző, hogy az oktatócsomagokat szakatnári teameben készítjük.

Külső segítséget veszünk igénybe az oktatócsomagok elkészítésénél.

Nem készítünk oktatócsomagot.

\subsection{Oktatócsomagjainkat az alábbi technikai háttér jellemzi (többet is megjelölhet)}

$\square$ CD-re, DVD-re írjuk azokat

$\square$ nyomtatott dokumentumokat készítünk

fájlmegosztókon tesszük közzé anyagainkat

egyéb eszközöket veszünk igénybe

$\square$ nem készítünk oktatócsomagot

2.14. Fejezze be az alábbi mondatot!

Intézményünkben a tutori rendszer

$$
\begin{aligned}
& \square \text { kifejezetten eredményes } \\
& \square \text { átlagosan múködő } \\
& \square \text { nem túl eredményes } \\
& \square \text { nincs ilyen. }
\end{aligned}
$$

2.15. A tutor az alábbi módon/eszközökkel kommunikál a tanulókkal (egyszerre több választ is megjelölhet)

$\square$ e-mail $\quad \square$ telefon $\quad \square$ skype $\quad \square$ facebook $\quad \square$ egyéb 
2.16. Tanulóik az oktatócsomag használatán és a konzultációkon / tutoráláson túl használnak egyéb segítséget a felkészülés során?

$\square$ igen

$\square$ nem

2.17. Amennyiben igen, kérem, jelölje meg a segítséget: (több is lehet)

$\square$ utána olvasnak az Interneten, szakkönyvekben

$\square$ magántanárhoz járnak

ismerősök segítenek

egyéb

\subsection{Mennyire ért egyet az alábbi állításokkal?}

A távoktatásban tanítók pedagógiai szerepe eltér a hagyományos pedagógus-szerepektől, sokkal inkább a piaci követelményeknek engedelmeskedik.

$\square$ teljes mértékben egyetért $\quad \square$ részben egyetért $\quad \square$ nem ért vele egyet

\subsection{Mennyire ért egyet az alábbi állításokkal?}

A távoktatásban nő a nem-pedagógiai feladatok ellátók száma, a „tantestület” létszáma viszont csökken.

$\square$ teljes mértékben egyetért $\quad \square$ részben egyetért $\quad \square$ nem ért vele egyet

\subsection{Mennyire ért egyet az alábbi állításokkal?}

A távoktatásban tanítóknak sokkal inkább alkalmazkodniuk kell a „menedzsment” döntéseihez, mint a hagyományos oktatásban résztvevőknek.

$\square$ teljes mértékben egyetért $\quad \square$ részben egyetért $\quad \square$ nem ért vele egyet

\subsection{Mennyire ért egyet az alábbi állításokkal?}

Ahhoz, hogy a távoktatás költséghatékony legyen, a pedagógiai döntéseket gyakran alá kell vetni egyéb körülményeknek (pl. az oktatócsomagok elkészítésének és terjesztésének technikai háttere).

$\square$ teljes mértékben egyetért $\quad \square$ részben egyetért $\quad \square$ nem ért vele egyet

\subsection{Mennyire ért egyet az alábbi állításokkal?}

A távoktatás IKT körülményei még fejlesztésre szorulnak a köznevelés rendszerében.

$\square$ teljes mértékben egyetért $\quad \square$ részben egyetért $\quad \square$ nem ért vele egyet 